1999

\title{
Intra-marital Sharing Rules with Evidence from Turkey
}

Nejat Anbarci

Florida International University

E. Mine Cinar

Loyola University Chicago

Follow this and additional works at: https://ecommons.luc.edu/meea

Part of the Economics Commons

\section{Recommended Citation}

Anbarci, Nejat and Cinar, E. Mine, "Intra-marital Sharing Rules with Evidence from Turkey". Topics in Middle Eastern and North African Economies, electronic journal, 1, Middle East Economic Association and Loyola University Chicago, 1999, http://www.luc.edu/orgs/meea/

This Article is brought to you for free and open access by the Journals and Magazines at Loyola eCommons. It has been accepted for inclusion in Topics in Middle Eastern and North African Economies by an authorized administrator of Loyola eCommons. For more information, please contact ecommons@luc.edu.

(C) 1999 by the authors 


\title{
INTRA-MARITAL SHARING RULES WITH EVIDENCE FROM TURKEY
}

\author{
Nejat Anbarci, Department of Economics, E-mail: anbarcin@fiu.edu \\ E. Mine Cinar*, Department of Economics, E-mail:mcinar@luc.edu
}

\section{Introduction}

Economists have long neglected distribution issues within the household by considering the household as a homogeneous and harmonious decision-making unit where the spouses have equal power. .A well-known empirical fact is that women, in general, earn less than men. In 1986, the U.N. Commission on the Status of Women reported: While women represent half the global population and one-third of the labor force, they receive only one tenth of the world income ... . They are also responsible for two-thirds of all working hours (quoted in Folbre (1986, p. 22)). A substantial body of literature suggests that a woman's power within the household is related to her contribution to the household's financial resources (see Browning et al (1992) and Phipps and Burton (1992), for instance).

Several studies suggest that a woman's power within household is related to her income. Empirical evidence presented here, however, suggests that spouses' personal spending levels are more or less egalitarian in significantly many cases. In this paper, we provide a simple formal model to show, among other things, that an egalitarian intra-household division of surplus income under certain circumstances is consistent with the fact that women typically earn lower wages than men. In our model we focus on two sharing rules to divide the income surplus: egalitarian and proportional. In the former, the personal spending levels of the spouses are equal; in the latter, the ratio of these spending levels is equal to the ratio of their incomes. We consider A SIMPLE game where the husband decides whether to make an egalitarian offer or a proportional offer. Whichever offer he decides to make has to be accepted by the wife for all periods that follow; otherwise a divorce follows.

In our model, in the absence of complete and perfectly enforceable marital contracts, the egalitarian marriage (i.e., the efficient marriage with a complete or high degree of specialization in Becker (1985)'s framework) turns out to be an equilibrium outcome given certain parameters.

There are circumstances under which the husband does not even settle for the egalitarian marriage and makes the proportional offer even if it is going to cause a divorce. As will be seen, the wife, unless the alimony is too generous, prefers an egalitarian marriage to any other outcome. When her alimony is low and divorce cost is high, she will accept even a proportional offer. In that case, a proportional marriage arises as the equilibrium outcome. Under some circumstances, the male chooses not to propose marriage.

In the two important initial papers on intra-household bargaining, Manser and Brown (1980) and McElroy and Horney (1981), used Nash's cooperative bargaining framework, where the threat point is the divorce outcome; consequently, any change in the threat point affects the distribution of utility within the marriage. Lundberg and Pollak (1993), on the other hand, suggests that the threat point need not be the divorce outcome but an uncooperative marriage, in which spouses' contributions to the household public goods turn out to be inefficient; it turns out that the intra-household distribution depends on who controls the household's resources. Becker (1985) examines time allocation within the marriage when home production and market production exhibit learning effects. The efficient outcome is specialization of tasks within the marriage, which is made possible by parties' commitment to a distribution through the course of their marriage via a prenuptial marriage contract in the marriage market. In Becker's model, the efficiency of time allocation is independent of the distribution within marriage due to the presence of complete and perfectly 
enforceable marital contracts. In a recent paper by Wells and Maher (1997), given a multi-period framework, spouses choose between allocating time to the household public good or career activities, both of which exhibit learning effects. While complete specialization is efficient, typically the outcome of this noncooperative setup turns out to be inefficient incomplete specialization. Wells and Maher (1997) and our paper are complementary in that their focus is on specialization and efficiency, whereas our focus is on the two sharing rules to divide the income surplus.

\section{Empirical Evidence}

To get an idea of income shares and the distribution of spending on self and spouse within the household and to measure proxies for dominance and happiness, a survey was conducted in Izmir, Turkey (see Cinar and Anbarci, 1998). Izmir is the third largest city in Turkey, with a population of 2.1 million residents. Table 1 gives the descriptive statistics of the survey sample.

TABLE 1: DESCRIPTIVE STATISTICS OF THE SAMPLE

$\begin{array}{lllllll}\begin{array}{l}\text { Sample size }= \\ \text { Variable }\end{array} & \text { Mean } & \text { Std.Dev. } & \text { Skew } & \text { Kurt } & \text { Min } & \text { Max } \\ & & & & & & \\ \text { NCHILD } & 1.5 & 1.1 & 0.4 & 3.4 & 0.0 & 6.0 \\ \text { YRSMAR } & 13.5 & 9.8 & 0.5 & 2.7 & 0.7 & 47.0 \\ \text { FAGE } & 35.2 & 9.3 & 0.5 & 3.2 & 19.0 & 68.0 \\ \text { FEDU } & 3.3 & 1.4 & 0.1 & 1.6 & 1.0 & 6.0 \\ \text { MAGE } & 39.4 & 9.6 & 0.4 & 3.2 & 22.0 & 75.0 \\ \text { MEDU } & 3.4 & 1.2 & 0.0 & 1.6 & 1.0 & 6.0 \\ \text { FYMORE } & 0.10 & 0.3 & 2.6 & 8.0 & 0.0 & 1.0 \\ \text { FYSAME } & 0.15 & 0.3 & 1.9 & 4.6 & 0.0 & 1.0 \\ \text { YRATIOW } & 0.35 & 0.1 & 0.1 & 2.7 & 0.1 & 0.8 \\ & & & & & & \\ \text { The following are in U.S. Dollars) } & & & & \\ \text { PRCPY1 } & 5,900.9 & 3,702.0 & 0.8 & 2.7 & 960.0 & 15,000.0 \\ \text { PRCPY2 } & 2,069.5 & 996.3 & 0.9 & 3.4 & 600.0 & 5,142.8 \\ \text { PRCPY3 } & 1,234.6 & 722.0 & 1.5 & 5.8 & 342.9 & 3,942.8 \\ \text { HHY1 } & 16,628.6 & 10,811.6 & 1.9 & 7.3 & 4,800.0 & 58,285.7 \\ \text { HHY2 } & 6774.9 & 3,322.9 & 3.8 & 22.0 & 2,400.0 & 25,714.2 \\ \text { HHY3 } & 4,450.1 & 2,436.7 & 1.6 & 5.2 & 1,371.0 & 11,828.5\end{array}$

\footnotetext{
ABBREVIATIONS

NCHILD: Number of children

YRSMAR: Years married

FAGE: Age, female

FEDU: Education, female (1-Illiterate, 2-Grade School, 3-Junior High, 4-Senior High,

5-University, 6-Graduate Degree)

MAGE: Age, male

MEDU: Education, male (same categories as in FEDU)

FYMORE: Ratio of wives who earn more than their husbands

FYSAME: Ratio of wives who earn the same as their husbands

YRATIOW: Income of woman as a ratio of household income

PRCPY: Annual per capita household income in U.S. dollars for each socio-economic stratum

HHY: Annual average household income in U.S. dollars for each socio-economic stratum
}

How does one measure power (defined as non-submissiveness or having a degree of control over one's life) or dominance within the household? Is it control over money and spending? In economics, the traditional proxy used for welfare is income and money. As a starting point, one can measure welfare or well-being of or power between spouses by assuming that power within the household is perfectly correlated with the income shares of husband and wife (see Browning et al (1992) and Phipps and Burton (1992)). In our sample, the number of women who earned more than their husbands in each of the socio-economic groups were $15 \%$ in upper, $4 \%$ in middle and $10 \%$ in lower socio-economic groups. In total, $35 \%$ of upper, $19 \%$ of middle and $20 \%$ of lower strata women earned about the same or more than their husbands in our sample. These numbers give one proxy of dominance within marriage.

(i) Egalitarian Outcome of Absolute Personal Expenditures: 
Income, however, is not necessarily a good measure of dominance. Altruistic or otherwise, spending on the household and the children have to be deducted to see how much, if any, is being spent on one's self. Net expenditures on self can be a better indicator of dominance in the household. Personal expenditures (such as personal haircare, makeup, clothes, reading materials, personal use of the car) were tallied and the absolute amounts of spending were compared between husband and wife. $22 \%$ of upper, $22 \%$ of middle and $24 \%$ of lower socio-economic strata women were found to have higher personal expenditures than men. In about 38 $\%$ to $46 \%$ of the time, men are found to have higher personal expenditures than women. In about $30 \%$ to 40 $\%$ of the households the expenditures are egalitarian (same). Thus, in about $54 \%$ to $62 \%$ of the households the personal expenditures are either egalitarian or favoring the women.

We find this result surprising. Most of the literature in developing countries cite that fathers tend to spend a great deal of the household income for their own personal expenditures. Our sample does not dispute this finding overall but shows that women with income spend on self at least as much as men in at least half the households across all three strata. Our finding says nothing about the priorities of women's spending. It could very well be that while some men spend on themselves regardless of the children, some women spend on children first and then spend the residual, if any, on themselves.

\section{(ii) Proportional Outcome of Personal Expenditures:}

Instead of the absolute value of personal expenditures, another proxy for dominance can be the proportional share of personal expenditures of husband and wife. That is, if we pool total household income and also total personal expenditures of husband and wife and compare the percentage of income shares to the percentage of personal expenditure shares, we can get another proxy for dominance. For example, a woman who earns 40 $\%$ of the household income but has a personal expenditures share of less than $40 \%$ would be considered submissive with respect to proportional outcome.

We found the majority of women in all three strata to be more dominant than men with respect to proportional outcome. We found that $70 \%$ of upper, $82 \%$ of middle and $62 \%$ of lower strata women have dominance greater than or equal to that of men in their marriage when dominance is defined with respect to proportional outcome. However, the dominance clearly observed for these women (with respect to both egalitarian and proportional outcomes) could be the result of non-dominance in other spheres of the marriage, where some women under stress find release in personal shopping. Another non-monetary measure of power could also be leisure time Yet the monetary proxies of dominance used so far are not totally inappropriate. In a separate question, $76 \%$ of upper, $44 \%$ of middle and $32 \%$ of lower socio-economic household women responding to the survey declared that they could do 'whatever they wanted'. $40 \%, 56 \%$ and $48 \%$ of the same groups stated that they were the dominant decision makers in the home.

\section{The Model}

We assume that both parties know all parameter values right from the outset (complete information). The husband decides whether to make an egalitarian or a proportional offer. Whichever offer he decides to make, it has to be accepted by the wife for all periods $t>1$; otherwise a divorce follows but the division of the surplus at $\mathrm{t}=1$ complies with the offer made by the husband.

We assume that the female works at a regular job at each $t \geq 1$ that pays a normalized wage of 0 (which is sufficient to cover her subsistence level). The husband contributes a normalized amount of 0 to the public good within the marriage. The wife contributes to the public good by $\mathrm{G}^{*}$ which enables the husband to earn a wage of $\mathrm{W}^{*}$. An egalitarian of surplus income here means $(1 / 2) \mathrm{W}^{*}$ for each party and a proportional distribution means 0 for the wife and $\mathrm{W}^{*}$ for the husband. If divorce occurs, then at $\mathrm{t}=2$ the female and the male incur divorce costs, $\mathrm{CF}$ and $\mathrm{CM}$ respectively. These costs entail court costs as well as psychic and other costs due to divorce. The wife, being the party that provided $\mathrm{G}^{*}$ to enable $\mathrm{W}^{*}$ initially and because of her low potential wage, may also be entitled to a portion $(0,1)$ of the man's after-divorce wage $\mathrm{W}$ each period $\mathrm{t}>$ 
1 following the divorce; thus, $\alpha \mathrm{W}$ is the alimony. The wife after divorce will enjoy her contribution to the previously public (and now private) good $\mathrm{G}^{*}$ solely.

In the normalized value functions below, $\mathrm{E}$ stands for egalitarian, $\mathrm{P}$ for proportional, $\mathrm{Y}$ for yes, and $\mathrm{N}$ for no (see endnote 1):

$\mathrm{VF}(\mathrm{E}, \mathrm{Y})=1 / 2 \mathrm{~W}^{*} /(1-\beta) \mathrm{VM}(\mathrm{E}, \mathrm{Y})=\left(1 / 2 \mathrm{~W}^{*}+\mathrm{G}^{*}\right) /(1-\beta)$

$\mathrm{VF}(\mathrm{E}, \mathrm{N})=1 / 2 \mathrm{~W}^{*}+\mathrm{DF} \mathrm{VM}(\mathrm{E}, \mathrm{N})=1 / 2 \mathrm{~W}^{*}+\mathrm{G}^{*}+\mathrm{DM}$

$\mathrm{VF}(\mathrm{P}, \mathrm{Y})=0 \mathrm{VM}(\mathrm{P}, \mathrm{Y})=\left(\mathrm{W}^{*}+\mathrm{G}^{*}\right) /(1-\beta)$

$\mathrm{VF}(\mathrm{P}, \mathrm{N})=\mathrm{DF} \operatorname{VM}(\mathrm{P}, \mathrm{N})=\mathrm{W}^{*}+\mathrm{G}^{*}+\mathrm{DM}$

The following lemma states the interrelationships among the various value functions:

LEMMA 0: (i) $V F(E, N)>V F(P, N)$, and $V F(E, Y)>V F(P, Y)$

(ii) If $0>D F$, then $V F(P, Y)>V F(P, N)$; otherwise, $V F(P, Y) V F(P, N)$.

(iii) If $1 / 2 W^{*} \beta /(1-\beta)>D F$, then $V F(E, Y)>V F(E, N)$; otherwise, $V F(E, Y) V F(E, N)$.

(iv) $V M(P, Y)>V M(E, Y)$, and $V M(P, Y)>V M(P, N)>V M(E, N)$.

(v) If $\left(1 / 2 W^{*}+G^{*}\right) \beta /(1-\beta)>D M$, then $V M(E, Y)>V M(E, N)$; otherwise, $V M(E, Y) V M(E, N)$.

(vi) If $\left(1 / 2 W^{*}(2 \beta-1)+G^{*} \beta\right) /(1-\beta)>D M$, then $V M(E, Y)>V M(P, N)$; otherwise, $V M(E, Y) V M(P, N)$.

(vii) The total welfare in $(E, Y)$ and $(P, Y)$ are the same. The total welfare in $(E, N)$ and $(P, N)$ are the same. The total welfare in any marriage is greater than in the break-up of the marriage.

The proof of this lemma follows from the definitions of $\operatorname{VF}(),. \operatorname{VM}($.$) as well as from the values of the$ parameters in a straightforward way. Our concept of equilibrium is backward induction.

\section{The Analysis of the Game}

Lemma 1 will be useful in establishing our main result (see endnote 2).

LEMMA 1: (i) If $D F<0$, then the wife's dominant strategy is to accept any offer.

(ii) If $1 / 2 W^{*} \beta /(1-\beta)>D F>0$, then the wife rejects the proportional offer but accepts the egalitarian offer.

(iii) If $D F>1 / 2 W^{*} \beta /(1-\beta)$, then the wife's dominant strategy is to reject any offer.

(iv) If $D M>\left(1 / 2 W^{*}(2 \beta-1)+G^{*} \beta\right) /(1-\beta)$, then the husband's dominant strategy is to make the proportional offer.

Our main result is as follows:

PROPOSITION 1: (i) If $0>D F$, then $(P, Y)$ is the equilibrium outcome.

(ii) If $1 / 2 W^{*} \beta /(1-\beta)>D F>0$ and $\left(1 / 2 W^{*}(2 \beta-1)+G^{*} \beta\right) /(1-\beta)>D M$, then $(E, Y)$ is the equilibrium 
(iii) If $D M>\left(1 / 2 W^{*}(2 \beta-1)+G^{*} \beta\right) /(1-\beta)$ and $D F>0$, then $(P, N)$ is the equilibrium outcome.

(iv) If $D F>1 / 2 W^{*} \beta /(1-\beta)$, then $(P, N)$ is the equilibrium outcome.

(v) $(E, N)$ is never an equilibrium outcome.

\section{Conclusion}

Women earn less than men in general, and a woman's power within a household is presumably related to her income level. Our empirical results, based on the survey conducted on two income households from Izmir, Turkey, indicate that the division of surplus income is more or less egalitarian in many cases. This, however, does not necessarily imply egalitarian personal leisure times.

Here, we have provided a model which, among other things, shows that an egalitarian intra-household distribution under certain circumstances is consistent with the fact that women earn lower wages than men. In our model, one crucial element is the link between the marital wage premium for the husband and the wife's contribution to the public good. To a large extent, this link and the fact that the divorce (and the stigma of divorce) removes this marital wage premium drive our results.

In our model, depending on the circumstances, either division of surplus income (as well as absence of marriage and divorce) can arise in equilibrium. As mentioned before, the egalitarian marriage is not the husband's first choice; when the wife would rather have a divorce than a proportional marriage, the husband settles for the egalitarian marriage in order not to lose his high marital wage premium and the wife's high contribution to the public good due to divorce.

One possible extension is to incorporate personal leisure levels, possibly using a measure of dominance which combines the levels of personal expenditures as well as leisure time. One can also consider incorporating a remarriage market. A fruitful direction for extension would be to include the possibility of domestic violence which can influence the type of division within the marriage.

\footnotetext{
*We thank Hassan Arvin-Rad, Arnab Basu, Cem Karayalcin, Rob Lemke, Devashish Mitra, Costas Syropoulos, Helen Tauchen, Robin Wells and Ann Witte, who read an earlier version of this paper and provided many useful comments and suggestions. We gratefully acknowledge Piar-Ege Research and Consulting Incorporated of Izmir, Turkey that helped make the survey feasible. In addition, we thank Aysenur Okten and Tezer Orhan for helping define power measures between spouses in Turkish households, Cigdem Orhan with survey and sampling design, Caglar Alkan for data entry.
}

\section{End Note}

1. The original value functions are: $U F(E, Y)=1 / 2 W^{*} /(1-\beta)+G^{*} /(1-\beta), U M(E, Y)=\left(1 / 2 W^{*}+G^{*}\right) /(1-\beta) ; U F(E, N)=1 / 2 W^{*}+$ $\mathrm{G}^{*} /(1-\beta)+\beta \alpha \mathrm{W} /(1-\beta)-\beta \mathrm{CF}, \mathrm{UM}(\mathrm{E}, \mathrm{N})=1 / 2 \mathrm{~W}^{*}+\mathrm{G}^{*}+\beta(1-\alpha) \mathrm{W} /(1-\beta)-\beta \mathrm{CM} ; \mathrm{UF}(\mathrm{P}, \mathrm{Y})=\mathrm{G} * /(1-\beta), \mathrm{UM}(\mathrm{P}, \mathrm{Y})=(\mathrm{W} *+$ $\left.\mathrm{G}^{*}\right) /(1-\beta) ; \mathrm{UF}(\mathrm{P}, \mathrm{N})=\mathrm{G}^{*} /(1-\beta)+\beta \alpha \mathrm{W} /(1-\beta)-\beta \mathrm{CF}, \mathrm{UM}(\mathrm{P}, \mathrm{N})=\mathrm{W}^{*}+\mathrm{G}^{*}+\beta(1-\alpha) \mathrm{W} /(1-\beta)-\beta \mathrm{CM}$. Observe that G*/(1- $\left.\beta\right)$ appears in each UF(.). Thus, for simplicity, we can normalize each UF( .) by subtracting $\mathrm{G}^{*} /(1-\beta)$. Also, whenever convenient, we can abbreviate the present value of the wife's 'divorce' payoff $\beta \alpha \mathrm{W} /(1-\beta)-\beta \mathrm{CF}$ by DF, and the present value of the husband's 'divorce' payoff $\beta$ (1- $\alpha) \mathrm{W} /(1-\beta)-\beta \mathrm{CM}$ by DM. Hence, we will use the following simplified value functions.

2. Proofs of results can be obtained from authors. 


\section{Bibliography}

Anbarci, N. (1993), Noncooperative Foundations of the Area Monotonic Solution, Quarterly Journal of Economics, 108, 245-58.

Anbarci, N. (1995), Reference Functions and Balanced Concessions in Bargaining, Canadian Journal of Economics,28, 675-82.

Anbarci, N. and J.P. Bigelow (1994), The Area Monotonic Solution to the Cooperative Bargaining Problem, Mathematical Social Sciences, 28, 133-42.

Anbarci, N. and E.M. Cinar (1997), Intra-Household Division of Surplus Income: Theory and Evidence, Working Paper No. 97-8, Department of Economics, Florida International University.

Becker, G. (1985), Human Capital Effort and Sexual Division of Labor: Part 1, Journal of Labor Economics, 3, S33-S58.

Bergstrom, T. (1996), Economics in a Family Way, Journal of Economic Literature, 34, 1903-34.

Bigelow, J.P. and N. Anbarci (1993), Non-Dictatorial, Pareto-Monotonic, Cooperative Bargaining: An Impossibility Theorem, European Journal of Political Economy, 9, 551-558.

Browning, M., F. Bourgouignon, P.A. Chiappori, and V. Lechene (1994), Income and Outcomes: A Structural Model of Intra-household Allocation, Journal of Political Economy, 102, 1067-96.

Cinar, E. M. and N. Anbarci, (1998), Measuring Spousal Power Within Two-Income Turkish Households, Working Paper, Department of Economics, Loyola University Chicago.

Cinar, E.M. (1994), Unskilled Urban Migrant Women and Disguised Employment: Home-Working Women in Istanbul, Turkey, World Development, 22, 369-80.

Folbre, N. (1986), Cleaning House: New Perspectives on Households and economic Development, Journal of Economic Development, 22, 5-40.

Hersch, J. and L. Stratton (1997b), Household Specialization and the Male Marriage Wage Premium, mimeo.

Kazgan, G. (1978), Women's Labor Force Participation, Job Distribution, Education Level and SocioEconomic Status in the Turkish Economy (in Turkish), in N. Abadan-Unat, ed., Turk Toplumunda Kadin (Ankara: Turk SosyalBilimler Dernegi).

Kuyas, N. (1982), The Effects of Female Labor on Power Relations in the Urban Turkish Family, in C. Kagitcibasi, ed., Sex Roles, Family and Community in Turkey (Bloomington: Indiana University Press).

Lazear, E. and R.T. Michael (1988), The Allocation of Income within the Household (Chicago: University of Chicago Press).

Lundberg, S. and R.A. Pollak (1993), Separate Spheres Bargaining and the Marriage Market, Journal of Political Economy, 101, 998-1010.

Lundberg, S. and R.A. Pollak (1996), Bargaining and Distribution in a Marriage, Journal of Economic Perspectives, 10, 139-158. 
Manser, M. and M. Brown (1980), Marriage and Household Decision Making: A Bargaining Analysis, International Economic Review, 21, 31-44.

McElroy, M..B. and M.J. Horney (1981), Nash Bargained Household Decisions, International Economic Review, 22,333-49.

Phipps, S. and P. Burton (1992), What is Mine is Yours? The Influence of Male and Female Incomes on Patterns of Household Expenditure, Discussion Paper No. 92-12, Department of Economics, Dalhousie University.

Phipps, S. and P. Burton (1995), Sharing within Families: Implications for the Measurement fo Poverty among Individuals in Canada, Canadian Journal of Economics, 28, 177-204.

Pollak, R.A. (1985), A Transaction Cost Approach to Families and Households, Journal of Economic Literature, 23,581-608

Tauchen, H.V., A. Witte, and S.K. Long (1991), Domestic Violence: A Nonrandom Affair, International Economic Review, 32, 491-511.

Wells, R. and M. Maher (1997), Time and Surplus Allocation Within Marriage, mimeo. 